\title{
Status of BIM implementation in the Dominican Republic construction industry - An empirical study
}

\author{
Ana Karina Silverio ${ }^{1}$, Subashini Suresh ${ }^{2}$, Suresh Renukappa ${ }^{2}$, and David Heesom² \\ ${ }^{1}$ Department of Architecture and the Built Environment, \\ University of the West of England, Frenchay Campus, Bristol, United Kingdom \\ ${ }^{2}$ Faculty of Science and Engineering, \\ University of Wolverhampton, Wolverhampton, United Kingdom
}

\begin{abstract}
Purpose: The increased use and proven benefits of Building Information Modelling (BIM) worldwide suggest that its implementation could greatly help diminish inefficient, traditional practices in the Dominican Republic (DR) construction industry. However, there is no empirical work about the implementation of BIM in the country. Therefore, this study aims to critically appraise and document the status of BIM implementation in the DR to raise awareness and understand how BIM can be successfully implemented in the country.

Design/methodology/approach: A qualitative approach was adopted in which data was collected through semi-structured interviews, with the participation of 53 professionals from 36 construction organisations. The data collected was analysed with the method of content analysis.

Findings: The results confirmed that the DR is a BIM infant country. There are low levels of BIM implementation. The reasons why BIM is not implemented are explored, and a significant interest in implementing BIM in the future is also reported. Drivers to implement BIM include BIM benefits, competitive advantage and pressure from external partners. Current BIM approaches are mainly single-disciplinary, principally in Architecture, and the effectiveness and scope of implementation are highly affected by intra-organisational and inter-organisational barriers.

Originality/value: There is a lack of research about BIM in the DR. This study bridges this research gap by collecting primary data from Dominican construction organisations and construction professionals to report findings related to BIM implementation.

Keywords: Building Information Modelling (BIM), BIM implementation, BIM infant country, construction industry, developing country, Dominican Republic, Latin America
\end{abstract}




\section{Introduction}

The Dominican Republic (DR) is a Caribbean country that has been generally known for being an exporter of coffee, sugar and tobacco. However, agriculture has been surpassed by the growth of the services sectors such as construction, tourism and free trade zones (Central Intelligence Agency (CIA), 2020). The construction industry has contributed significantly to the economy's growth of the country (Soler et al., 2013). This sector has evolved substantially over the past three decades thanks to the low rate loans and mortgages (Department for International Trade, 2020) as well as the investment from the public and private sector in residential projects, programmes to increase the number of affordable and mid-range housing, touristic hotels and infrastructure works (Banco Central Republica Dominicana, 2021). However, despite showing sustainable and continuous growth, the Dominican construction industry is lacking, in many cases, a qualified workforce and innovative and efficient construction techniques (Soler et al., 2013). Other barriers hindering productivity in the sector include the quality of the materials, documenting agreements and procedures, understanding the necessities of internal and external clients, well-defined team focus, and communication between teams (Senior and Rodriguez, 2012).

In the presence of these needs and due to the advent of BIM implementation worldwide and the proven benefits of BIM in this regard, the implementation of BIM comes into view as key to improve current practices and open the way for the digitalisation of the Dominican construction industry. Currently, the implementation of BIM in the Dominican construction industry is undocumented. Therefore, fundamental questions need to be addressed to understand how BIM implementation can be realised. Against this backdrop, this research has been developed to investigate the status of BIM implementation in the country. This paper starts with a theoretical background on BIM and its benefits. Then, it presents the status of global BIM implementation, highlighting the problems of low levels of implementation and lack of research in late adopters and developing countries. A discussion on BIM implementation in Latin America is also included because of the relevance of studying BIM implementation within the geographical context of the DR. Subsequently, information about the BIM implementation in the DR is presented. Then, the methodology adopted is explained, followed by the findings, discussion and conclusions.

\section{Theoretical background}

Construction is an important industry worldwide; however, compared to other sectors, the construction industry has experienced problems to evolve its methods, and its productivity has been affected accordingly (Mckinsey Global Institute, 2017). Many construction projects have suffered from issues such as poor quality, time delays and cost overrun. The most common reasons for this productivity decrease encompass lack of communication, insufficient exchange of project information, low productivity percentages, high rates of rework and inefficiency, adversarial relationships between partners, constant disagreements, and lack of innovation (Ahuja et al., 2017). For these reasons, the industry requires a more productive approach, which can be achieved through the implementation of digital technologies (Mckinsey Global Institute, 2017). Currently, there is some indication of digital transformation within the construction industry with the emergence of Building Information Modelling (BIM) (Li et al., 2019).

$\mathrm{BIM}$ is "a set of interacting policies, processes and technologies generating a methodology to manage the essential building design and project data in digital format throughout the building life cycle" (Succar, 2009). BIM can be seen as a virtual process that includes all the aspects, 
disciplines and systems of a project in a single, virtual model that enables project's participants (architects, engineers, contractors, subcontractors, suppliers and clients) to collaborate more effectively and accurately than traditional practices. While the model is being developed, project members regularly improve and make changes in their areas of expertise conforming to project specifications to ensure the model's accuracy before it is physically constructed. BIM is a combination of process and software. It requires an intelligent model and essential changes in the workflow and project delivery processes (Azhar, 2011).

BIM can be potentially used at all stages of the project lifecycle, from initial design stages through construction to operation and eventually demolition (Eadie et al., 2013a; Ghaffarianhoseini et al., 2017). BIM can be used for design, construction and management. It is currently being implemented in inter-organisational design coordination, automatic detection of design-related errors, automated building design review, construction safety management, identification and prevention of hazards, and construction risk management (Ghaffarianhoseini et al., 2017). In terms of project actors, BIM can be used by owners to understand project's needs; by the design team to analyse, design and develop the project; by contractors to manage the construction of the project; and by facility managers throughout the operation and decommissioning phases (Bryde et al., 2013). BIM facilitates a new method of working through a common environment that stores all the information of a building or asset, along with its components and activities (Merschbrock and Munkvold, 2015). As a collaborative technology, BIM offers the construction industry an opportunity for integration and is perceived as a feasible response to the communication-related issues that affect the construction industry (Mahamadu et al., 2017).

\section{Global BIM implementation}

BIM implementation is rapidly increasing around the world. This growth has been mainly driven by the need for more efficient workflows and a better understanding of the whole project lifecycle (BIM Wiki, 2018b). The implementation of BIM has also been propelled by government entities engaged with construction activities and major private owners who want to standardise its benefits for faster and more accurate project delivery and more reliable cost and quality (McGraw-Hill Construction, 2014a). Nowadays, many important economies have set a BIM mandate or are thinking of developing one (McGraw-Hill Construction, 2014b). Countries with national BIM mandates for specific public projects include Denmark, Finland, Norway, Singapore, UK (McGraw-Hill Construction, 2014b), Hong Kong (Mott Macdonald, 2018), Chile (Soto, 2016) and Brazil (ABDI, 2021). Other examples are the United States of America and the United Arab Emirates, with mandates established by governmental departments rather than nationwide (McGraw-Hill Construction, 2014b).

Despite its benefits, the global development of BIM in the construction industry is still infant. The diffusion among industry professionals around the world has been lower than expected (Cao et al., 2015; Rahim and Zakaria, 2017), limited to the technical level (Hua, 2014) and has not been fully achieved even in leading markets (Ghaffarianhoseini et al., 2017). Furthermore, the implementation has been usually slower than the targets set by many governments across the world (Adamu and Ayinla, 2018). That can be attributed to the observed challenges and risks at the current stage of the technology's development and its supporting methods and standards (Li et al., 2019). BIM adoption also varies significantly by country and level of economic development (World Economic Forum, 2018). Mehran (2016) noted that BIM adoption has been slow, 
particularly in late adopter countries. Jayasena and Weddikkara (2013), Bui et al. (2016), and Ismail et al. (2017) further stated that BIM is being adopted progressively in developed countries, but the adoption levels in emerging or developing countries are low. Developed countries are more advanced because of the collective efforts from governments and organisations (Saka et al., 2020) and the provision of industry-wide guidance to assist the BIM adoption journey, which is not usually available in developing countries (Ahuja et al., 2018). The construction industry in developing countries is affected by numerous challenges, including time and cost overruns, project delays, project desertions, disputes, corruption and generation of waste, which could be mitigated by the adoption and implementation of BIM (Saka et al., 2020). However, there is limited research about BIM in emerging markets (Ahuja et al., 2018), which is vital to promote BIM implementation in these countries.

BIM implementation in Latin America

The implementation of BIM is emerging in Latin America but showing some progress in recent years. Two surveys have been conducted to evaluate BIM implementation in the region. The first survey was carried out in 2017, and the results indicated that Chile (32\%), Brazil (27\%) and Colombia (18\%) were the primary users of BIM in the region (INCONET, 2017). The last and more comprehensive survey was conducted in 2020. The survey presented similar results to the previous one, with Brazil, Chile, Colombia and Argentina as the main BIM users, accounting for more than half of the participant countries (54\%) (Lacaze, 2020).

Important groups are promoting the implementation of BIM in Latin America and collaboration between countries. For example, BIM Forum Latam is a specific working group from the FIIC (Inter-American Federation of the Construction Industry) that gathers several BIM forums from Latin American and Spain (BIM Forum Chile, 2017). Another important organisation is the "BIM network of Latin American governments" (Red BIM de Gobiernos Latinoamericanos in Spanish), created in 2019. The network is financially supported by the Inter-American Development Bank (BID in Spanish) and constituted by public sector representatives from Latin America. Currently, its members are Argentina, Brazil, Chile, Colombia, Costa Rica, Mexico, Peru and Uruguay (Red BIM Gob Latam, 2020a,b).

In terms of BIM mandates, the pioneer in the region has been Chile with the strategy "Plan BIM" in 2016, which proposes the gradual implementation of BIM in 10 years (Soto, 2016; Planbim, 2018). Subsequently, Brazil, Mexico, Argentina and Peru published their national BIM strategies to mandate BIM in public projects. The most recent efforts are from Colombia, Costa Rica and Uruguay. Table 1 presents more detailed information about the national BIM strategies in these countries.

Table 1: Key BIM strategies from governmental and public entities in Latin America

\begin{tabular}{|c|l|}
\hline Country & \multicolumn{1}{c|}{ Strategies } \\
\hline Argentina & $\begin{array}{l}\text { 2017: Creation of the "BIM Strategy Argentina" (Estrategia BIM Argentina (EB-AR) in Spanish) } \\
\text { by the Secretariat of Territorial Planning and Coordination of Public Works from the Ministry of } \\
\text { Interior, Public Works and Housing. The strategy aims to implement BIM at a national level with a } \\
\text { roadmap defined until 2025 (BIM Forum Argentina, 2018). }\end{array}$ \\
\hline
\end{tabular}




\begin{tabular}{|c|c|}
\hline & $\begin{array}{l}\text { 2019: Introduction of the BIM implementation plan for public projects through the programme } \\
\text { SIBIM (BIM implementation system) (Portal Oficial del Estado Argentino, 2019). }\end{array}$ \\
\hline Brazil & $\begin{array}{l}\text { 2017: Creation of the CE-BIM (Strategic Committee of BIM implementation) by the Brazilian } \\
\text { Federal Government to propose a national strategy for disseminating BIM (SECOVI-SP, 2017). } \\
\text { 2018: Introduction of the "BIM BR Strategy" (Estrategia BIM BR in Portuguese), which } \\
\text { encompasses nine objectives for the successful implementation and diffusion of BIM as well as a } \\
\text { gradual mandatory use of BIM for public procurement from 2021-2028 (Red BIM Gob Latam, } \\
\text { 2020b; ABDI, 2021) }\end{array}$ \\
\hline Chile & $\begin{array}{l}\text { 2014: Announcement of the National Programme "Build 2025" (Construye } 2025 \text { in Spanish) by } \\
\text { the Chilean president (Construye, 2016). } \\
\text { 2016: Launch of Plan BIM, a } 10 \text {-year programme led by CORFO (Corporation of Production } \\
\text { Development) within the national programme "Build } 2025 \text { ", which establishes the gradual } \\
\text { implementation of BIM from } 2016 \text { to } 2025 \text { (Soto, 2016; Planbim, 2018). }\end{array}$ \\
\hline Colombia & $\begin{array}{l}\text { 2020: the National Planning Department officially launched the "Strategy of BIM Adoption } \\
\text { Colombia" (Estrategia de Adopcion BIM Colombia in Spanish) to drive digital transformation in } \\
\text { the construction sector. The strategy aims to develop public projects with BIM by } 2026 \text {, with } \\
\text { progressive planning from } 2020 \text { to } 2026 \text { (CAMACOL (Camara Colombia de la Construccion), } \\
\text { 2020; Red BIM Gob Latam, 2020b). }\end{array}$ \\
\hline Cost & $\begin{array}{l}\text { 2019: Creation of the CII-BIM (Inter-institutional Commission for the implementation of BIM } \\
\text { methodology) to formulate strategic actions for a national BIM strategy (mideplan, 2019). } \\
\text { 2020: Presentation of "National BIM Strategy Costa Rica" (Estrategia Nacional BIM Costa Rica } \\
\text { in Spanish) supported by the Presidential Office through the First Lady's Office. The strategy is } \\
\text { coordinated by the Mideplan (Ministry of National Planning and Economic Politics) and } \\
\text { financially supported by the Inter-American Development Bank (BID in Spanish). The initial } \\
\text { phase of the strategy is within the period 2020-2024. }\end{array}$ \\
\hline Mexico & $\begin{array}{l}\text { 2018: Presentation of the "Strategy for the implementation of BIM in Mexico" (Estrategia para la } \\
\text { implementacion de MIC en Mexico in Spanish) by the Secretariat of Treasury and Public Credit } \\
\text { (SHCP). The strategy has an eight-year roadmap from } 2018-2026 \text { (SHCP, 2019) }\end{array}$ \\
\hline Peru & $\begin{array}{l}\text { 2019: Introduction of the Plan BIM Peru, an initiative included within the National Plan for } \\
\text { Competitiveness and Productivity (2019-2030). Plan BIM Peru was created by the Ministry of } \\
\text { Economy and Finance (MEF). It contains four milestones to be achieved between 2019-2030 } \\
\text { (BuildingSMART Spain, 2019; MEF, 2020). }\end{array}$ \\
\hline Uruguay & $\begin{array}{l}\text { 2019: Creation of the "BIM National Committee" (Comite Nacional BIM in Spanish) to lead BIM } \\
\text { adoption at a national level, focusing on public projects. The committee is integrated by several } \\
\text { ministries, government agencies and organisations from the private sector. The strategy is set to be } \\
\text { completed from } 2019 \text { to } 2025 \text { (Uruguay Presidencia, 2019; Red BIM Gob Latam, 2020b) }\end{array}$ \\
\hline
\end{tabular}

\section{Research gap}

The Dominican government has not publicly expressed any interest in mandating the use of BIM in the country. Therefore, there is no clear guidance on how BIM can be implemented in the country, which is the case of many emerging markets worldwide (Ahuja et al., 2018). Nonetheless, a few governmental initiatives that can pave the way for this scenario in the future have been identified. For instance, the project "Electronic government" (Gobierno electronico in Spanish), created to provide transparent services with an inter-connected government and the development of Information and Communication Technologies (ICT) (Portal Oficial de la Republica Dominicana, 2016). Furthermore, "Digital Republic" (Republica Digital in Spanish), a governmental programme for the presidential term 2016-2020 that aimed to give access to ICT to all Dominican citizens to bridge the current digital gap and provide better services to citizens (Ministerio de la Presidencia, 2016a). This programme has been substituted in 2021 by a new programme, "Digital Transformation Cabinet" (Gabinete de Transformacion Digital in Spanish), 
for the presidential term 2020-2024 that will continue its work (Presidencia de la Republica Dominicana, 2021). Lastly, "Connected city councils" (Municipio conectados in Spanish), a project within the former "Digital Republic" scheme to modernise city councils through the creation of web pages to offer municipal services through the internet (Ministerio de la Presidencia, 2016b).

A significant step in the construction sector has been the creation of a portal web for the department of building's permit of the Ministry of Public Works and Communications (MOPC), which is available since the $1^{\text {st }}$ of November of 2018. In addition, the department is involved in an internal digitisation process seeking to shorten the building's permit process (Arias, 2018).

An important BIM advancement has been the creation of the BIM Forum Republica Dominicana in 2020, which aims to promote and spread BIM implementation to increase the productivity of the Dominican construction sector. The forum was created with the joint efforts of the Dominican Construction Chamber (CADOCON in Spanish) and four important Dominican construction firms (CADOCON, 2020). The forum is part of the BIM Forum Latam (BIM Forum Latam, 2020), which would facilitate collaboration with other BIM forums and entities of the Latin America region. The DR has taken part in the two surveys mentioned above in Latin America. Still, the participation has been limited to draw conclusions about the levels of BIM implementation in the country. However, a positive outcome from the last survey in 2020 was the inclusion of a hospital project in Santo Domingo developed by a Dominican company as a case study of BIM in Latin America (Lacaze, 2020). This example of good practice has made the work done in the DR in BIM implementation notorious in the region.

There is limited information about the status of BIM in the DR. BIM implementation in the country is emerging, but at a low pace compared to advanced countries and some Latin American countries that already have national BIM strategies. This gap in knowledge has presented an opportunity to investigate the implementation of BIM in the country and explore how BIM implementation can be realised. The following section presents the research methodology developed to achieve this aim.

\section{Research methodology}

Currently, there is limited literature available about the implementation of BIM in the Dominican Republic. This paucity of research suggested the adoption of qualitative research. As indicated by Creswell (2014), a qualitative approach is appropriate when the subject of study has never been confronted with a specific sample or group of people, which is the case of the Dominican Republic.

\section{Data collection}

Data was collected through semi-structured interviews because they offer the flexibility needed in this study for interviewees to express themselves and topics to emerge freely but still ensure that the conversation is structured enough for subsequent data analysis (Bryman, 2016; Saunders et al., 2019). The sample were professionals of the construction industry belonging to construction organisations in the Dominican Republic. The inclusion criteria to select the professionals were 
that they must be a permanent staff of construction organisations and have extensive knowledge of how the organisation works and develops their projects. In terms of the construction organisations, the criteria included primarily to have developed at least one construction project. The criteria did not require the organisations to implement BIM as it was expected not to find many organisations implementing it due to the undocumented state of BIM in the country. It was concluded that the inclusion of organisations not implementing BIM would offer valuable insight related to the status of BIM in the country.

There are no public databases of the construction industry in the Dominican Republic where the researcher could initiate contact with potential candidates for this research. For that reason, the professional background of the researcher was used as a starting point to sample the first participants of this study, and the snowball sampling strategy was adopted to grow this sample. In total, 53 interviewees from 36 construction organisations were interviewed to critically appraise and document the implementation of BIM in the Dominican construction industry (See Table 2). This sample size was determined by data saturation (Charmaz, 2006) and is within what is acceptable in qualitative research (Creswell and Poth, 2017; Saunders et al., 2019).

Table 2: Profile of the interviewees that participated in the preliminary study the interviews directed to construction organisations

\begin{tabular}{|c|c|c|c|}
\hline Interviewee & Profession & Role in the organisation & Organisation \\
\hline 1 & Architect & Architect designer & 1 \\
\hline 2 & Architect & President of the company & 2 \\
\hline 3 & $\begin{array}{l}\text { Electronic and } \\
\text { Communication Engineer }\end{array}$ & Project manager & \\
\hline 4 & Civil Engineer & Cost analyst & 3 \\
\hline 5 & Architect & Senior Architect & 3 \\
\hline 6 & Architect & Owner & 4 \\
\hline 7 & Architect & CEO & 5 \\
\hline 8 & Architect & Architect & 5 \\
\hline 9 & Architect & Architect & 5 \\
\hline 10 & Architect & Architect & 5 \\
\hline 11 & Civil Engineer & Project's supervisor & 6 \\
\hline 12 & Civil Engineer & CEO & 7 \\
\hline 13 & Civil Engineer & President & 8 \\
\hline 14 & Civil Engineer & Project coordinator & 9 \\
\hline 15 & Architect & Architect & 10 \\
\hline 16 & Architect & Architect & 11 \\
\hline 17 & Civil Engineer & Project Manager & 12 \\
\hline 18 & Civil Engineer & $\begin{array}{l}\text { Cost estimation, construction planning and } \\
\text { project supervision }\end{array}$ & 13 \\
\hline
\end{tabular}


Journal of Engineering, Design and Technology

\begin{tabular}{|c|c|c|c|}
\hline 19 & Civil Engineer & BIM Coordinator & 14 \\
\hline 20 & Architect & BIM Coordinator & 12 \\
\hline 21 & Civil Engineer & Project's control & 12 \\
\hline 22 & Civil Engineer & Junior Resident Engineer & 15 \\
\hline 23 & Civil Engineer & Board's President and General manager & 12 \\
\hline 24 & Civil Engineer & Tekla BIM Coordinator & 16 \\
\hline 25 & Civil Engineer & Area coordinator (Resident Engineer) & 16 \\
\hline 26 & Architect & $\begin{array}{l}\text { Manager of the Architectural Department and } \\
\text { BIM coordinator at one project }\end{array}$ & 12 \\
\hline 27 & Civil Engineer & BIM Manager and BIM Coordinator & 17 \\
\hline 28 & Architect & Dir. of the Architectural Department & 18 \\
\hline 29 & Architect & Architect & 18 \\
\hline 30 & Civil Engineer & General Project Manager & 19 \\
\hline 31 & Civil Engineer & Project Manager & 20 \\
\hline 32 & Architect & $\begin{array}{l}\text { Owner and in charge of the Architectural } \\
\text { Design }\end{array}$ & 21 \\
\hline 33 & Architect & $\begin{array}{l}\text { Relocation planning manager of an Urban } \\
\text { regeneration project }\end{array}$ & 22 \\
\hline 34 & Civil Engineer & Project manager & 23 \\
\hline 35 & Architect & Owner & 24 \\
\hline 36 & Architect & Director of the drawing department & 25 \\
\hline 37 & Architect & Technical director & 26 \\
\hline 38 & Architect & Executive director & 27 \\
\hline 39 & Architect & Manager director & 27 \\
\hline 40 & Civil Engineer & Project manager & 28 \\
\hline 41 & Architect & General manager & 29 \\
\hline 42 & Civil Engineer & Technical Engineer & 30 \\
\hline 43 & Architect & Owner and Project's director & 31 \\
\hline 44 & Architect & Owner and Project's director & 31 \\
\hline 45 & Civil Engineer & Director and Project manager & 32 \\
\hline 46 & Architect & Director and Project manager & 32 \\
\hline 47 & Architect & $\begin{array}{l}\text { Supervision of materials' procurement and as- } \\
\text { built models. } \\
\text { Supervision of the construction. }\end{array}$ & 33 \\
\hline 48 & Civil Engineer & Cost Estimation and Project Planning & 34 \\
\hline 49 & Civil Engineer & $\begin{array}{l}\text { Owner of the company and Construction } \\
\text { Manager }\end{array}$ & 35 \\
\hline
\end{tabular}




\begin{tabular}{|l|l|l|l|}
\hline 50 & Architect & President of the company & 36 \\
\hline 51 & Architect & Architect in Supervision and construction & 36 \\
\hline 52 & Civil Engineer & In charge of construction & 36 \\
\hline 53 & Civil Engineer & Construction assistant & 36 \\
\hline
\end{tabular}

The interview guide was designed in two sections. The first section aimed to explore general information about the organisations. The second section aimed to enquire about BIM. The interview guide considered two alternatives for this section. When organisations were not related to BIM at all, the researcher would investigate the reasons why BIM has not been considered and get their insight about the implementation of BIM. On the other hand, when the organisations were involved with BIM implementation, the interview aimed to elicit specific aspects of the implementation.

\section{Data analysis}

Content analysis was the method selected for data analysis because of its appropriateness to carry out exploratory research in areas where there is not much known (Vaismoradi et al., 2013). Furthermore, the aim of this study only required the analysis of manifest content from the interviews, which is an option available in content analysis (Bengtsson, 2016). The research adopted specifically an inductive content analysis approach, which was primarily informed by the methods of Hsieh and Shannon (2005), Elo and Kyngäs (2008) and Cho and Lee (2014). It consisted of four phases: preparation, coding, abstraction and reporting phase (Refer to Figure 1). For the preparation phase, data was transcribed, inserted and organised in the qualitative data analysis software NVivo 11. The coding phase started with open coding, in which data was categorised analytically with codes. After open coding, a categorisation process was conducted to group the codes into categories, sub-categories, sub-sub-categories, etc. When creating the categories, the researcher had to ensure that data would not be allocated in more than one category. NVivo 11 assisted significantly in this regard. In the abstraction phase, categories were compared and checked iteratively to ensure that the allocation of the data and the creation of the categories were appropriate. After that, the researcher defined the main categories and developed general explanations from the data that emerged from the interviews. The last phase, namely reporting phase, consisted of communicating the content of the categories in a written manner, along with literature findings when required. Diagrams were also used to present findings and facilitate the identification of the categories' hierarchy. 


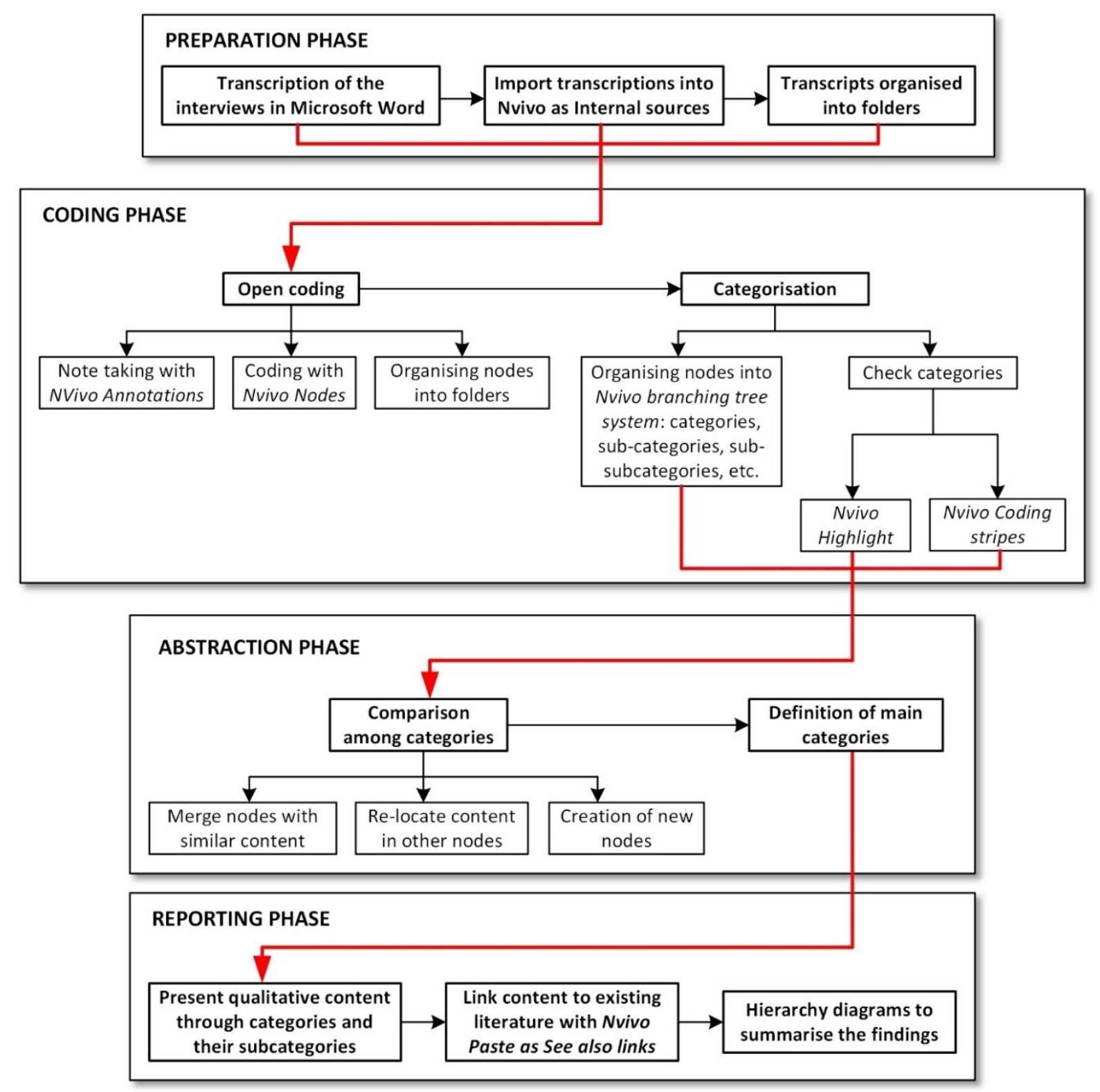

Figure 1: Inductive content analysis assisted by the software NVivo 12

To ensure credibility, the data analysis was validated through triangulation, peer review, and member checking processes. In terms of transferability, this study makes no claims that findings in other contexts will be similar to this study because qualitative data is context-specific. Nonetheless, since the readers decide to determine the transferability of a study to different settings, the researcher has provided a thorough description of the research process.

\section{Findings}

The findings presented in this paper include aspects of the status of BIM implementation in the Dominican Republic, such as reasons why BIM is not implemented, drivers for its 
implementation, issues encountered with the current implementation approaches and the current scope of implementation.

As presented in Table 3, the organisations that participated in the current study were classified according to their involvement with BIM in organisations not implementing BIM, organisations in transition to implementing BIM and organisations implementing BIM.

Table 3: Classification of the construction organisations according to their involvement with BIM

\begin{tabular}{|c|c|c|c|}
\hline $\begin{array}{l}\text { Classification } \\
\text { according to their } \\
\text { involvement with BIM }\end{array}$ & Organi sations & $\begin{array}{l}\text { Total of } \\
\text { organisations } \\
(\mathrm{N}=36)\end{array}$ & $\begin{array}{l}\text { Percentage (No. of } \\
\text { organisations/total no. of } \\
\text { organisations x 100) }\end{array}$ \\
\hline $\begin{array}{l}\text { Organisations that do } \\
\text { not implement BIM }\end{array}$ & $\begin{array}{l}1,2,3,4,6,7,8,9,10,14,15,20, \\
22,23,27,28,29,30,33,34,35, \\
36\end{array}$ & 22 & $61 \%$ \\
\hline $\begin{array}{ll}\text { Organisations } & \text { in } \\
\text { transition } & \text { to } \\
\text { implementing BIM } & \end{array}$ & $5,13,19,25$ and 31 & 5 & $14 \%$ \\
\hline $\begin{array}{l}\text { Organi sations } \\
\text { implementing BIM }\end{array}$ & $\begin{array}{l}11,12,16,17,18,21,24,26 \text { and } \\
32\end{array}$ & 9 & $25 \%$ \\
\hline
\end{tabular}

Organisations that do not implement BIM are organisations that do not implement any BIM-related process in their practices. This category also included organisations whose CEOs and directors had not made any organisational changes to adopt BIM. Twenty-two organisations were allocated in this category, which accounts for $61 \%$ of the organisations that participated in the study. The other organisations were involved with BIM but to different extents. Organisations interested in BIM that had already decided to implement it and were going through some organisational changes to attain this goal were categorised as organisations in transition to implementing BIM. Five organisations were allocated in this category, accounting for $14 \%$ of the organisations that participated in the study. Furthermore, organisations that were implementing some BIM-related processes in their practices and whose leaders and employees had a broad BIM knowledge were categorised as organisations implementing BIM. Nine organisations were allocated in this category, which accounts for $25 \%$ of the participant organisations.

This classification and the number of organisations in each category indicated that BIM implementation in the participant organisations was low as almost two-thirds (61\%) were not implementing BIM.

\section{Reasons why BIM is not implemented in the organisations}

By asking the question "Why is BIM not implemented in this organisation?", interviewees from the organisation that do not implement BIM explained the reasons why they were not implementing BIM. Following the content analysis method, these reasons were categorised in Intra-organisational and Inter-organisational reasons (see Figure 2Error! Reference source not found.). 


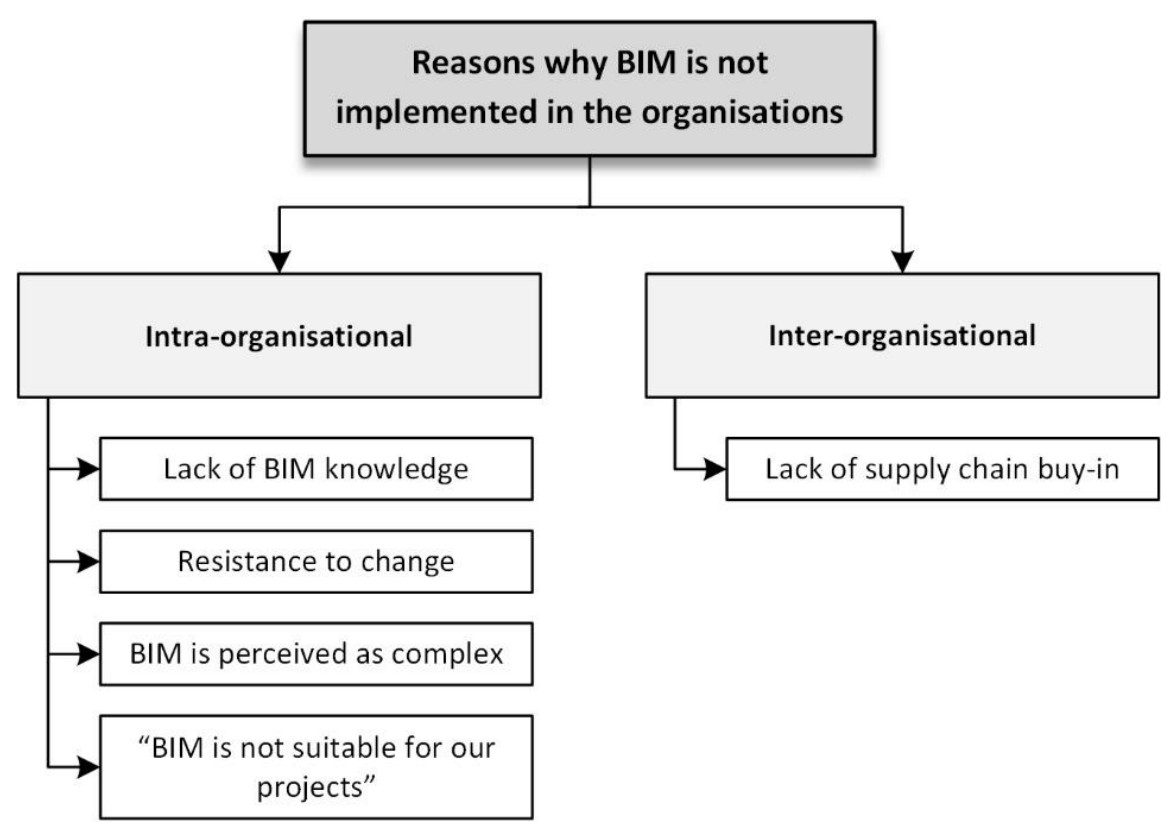

Figure 2: Reasons why BIM is not implemented in the organisations

The intra-organisational reasons identified by the interviewees include: Lack of BIM knowledge, Resistance to change, BIM perceived as complex, and "BIM is not suitable for our projects". Interviewees from 10 out of the 22 organisations identified Lack of BIM knowledge as one reason why BIM is not implemented in these organisations. The interviews discussed different aspects within this category. For instance, lack of BIM awareness from the leaders was identified in 2 organisations. Moreover, leaders from six organisations were aware of BIM but had a limited understanding of what BIM implies and the benefits of its implementation. Interviewees from Org. 27 and 36 expressed to be interested in implementing BIM. However, they stated they have not been able to do it because of the lack of knowledge on how to develop a plan to attain this goal:

"There are many things that you need to study to implement BIM. We need to look into that [...] We want to implement it in our company, and we are aware that there are certain aspects and workflows that we need to implement to achieve this goal" Interviewee 39, Org. 27.

Resistance to change traditional methods and adopt BIM can be caused by users' unawareness or dissatisfaction with BIM benefits and advantages (Batarseh and Kamardeen, 2017). This attitude towards BIM was reported by interviewees from four organisations. Two interviewees expressed that the leaders of the organisations were resistant to implement BIM because they were entrenched in traditional methods. For instance, Interviewee 11 from Org. 6 stated that "There is not any interest in implementing BIM in this institution because they are in a comfort zone in the way they are working at the moment".

The perceived complexity of innovation from members of a social system has a negative impact on its adoption rate (Rogers, 1995). BIM is being described as a complicated process by several studies. Moreover, BIM software has been considered too complex (Xu et al., 2014; Ahuja et al., 2016) and a hurdle to spread BIM adoption (Xu et al., 2014). In that respect, two interviewees 
from two organisations stated that BIM is not implemented in their organisations because the process and software used for the implementation are perceived as complex. Interviewee 15 from Org. 10 commented: "...my boss, who still uses AutoCAD, and the office, which has a system, didn't want to start implementing complex things such as BIM because if at any moment we leave the company and they need to revise a project, they won't understand the system".

Many individuals may be aware of numerous innovations that they have not decided to adopt yet. One reason for this decision can be that the innovation may not appear to be essential or beneficial for their circumstances. Hence, attitudes towards an innovation generally come between knowledge and decision making (Rogers, 1995). That was the case of interviewees from two organisations who acknowledged that BIM implementation is very beneficial. Nonetheless, they do not think it is suitable for the type of projects they usually develop: "It is not worth it for us to implement BIM for a plant treatment, but for a complex project such as an airport... its implementation is totally worth it" - Interviewee 42, Org. 30.

Organisations and professionals that want to offer BIM services will require their partners within the supply chain to be "BIM literate" to take full advantage of BIM's potential (Eadie et al., 2014).

Lack of supply chain buy-in was the only inter-organisational reason reported by the interviewees from five organisations. That was identified mainly in the lack of demand and BIM expertise among external partners (Eadie et al., 2014). For instance, Interviewee 14 from Org. 9 commented that BIM has never been required by members of the supply chain, while Interviewee 41 from Org. 29 stated that many designers they work with do not have BIM knowledge. Interoperability issues and lack of BIM software skills were other factors mentioned within this category by four out of the five organisations:

"We don't have the necessity of implementing BIM because if the ones we subcontractfeel comfortable with an X software, we can't force them to use BIM. It would be better if they implemented BIM" - Interviewee 40, Org. 28.

\section{Drivers for BIM implementation}

The factors that drive BIM implementation in the Dominican Republic construction were explored with all the organisations. Interviewees from the organisations that do not implement BIM were asked if BIM implementation would be considered in the future. Interviewees from 16 out of 22 organisations $(73 \%)$ stated that the organisations could consider the implementation in the future. Subsequently, interviewees indicated which potential drivers would encourage the implementation of BIM in the future. On the other hand, organisations in transition and implementing BIM explained which drivers have encouraged them to start and continue implementing BIM. Three drivers for BIM implementation were identified, namely BIM benefits, competitive advantage, and external pressure.

BIM benefits: BIM benefits are intrinsically drivers (Eadie et al., 2013b) and significantly influence BIM implementation (Al-Ashmori et al., 2020). Interviewees from 10 out of 16 organisations that do not implement BIM stated that BIM benefits might be the incentive of implementing BIM in the future. However, most interviewees were quite general when discussing which BIM benefits may motivate BIM implementation in the organisations. Explanations were primarily related to being aware of the benefits BIM can offer to their workflows and the 
enhancements they can realise in efficiency, time, facilitation of work, etc. For example, interviewee 15 from Org. 10 argued: “... it is a great resource that allows you to get a lot of information, the schedules, that you can update sections automatically.... We will start to implement it". Although correct, this statement denoted a limited knowledge of the whole scope of BIM implementation since these benefits are related to the parametric features of BIM software rather than the BIM process itself.

Moreover, interviewees from 3 organisations in transition to implementing BIM and 8 organisations already implementing BIM stated that their primary motivation was the benefits they can obtain through BIM implementation. A few of the interviewees from these organisations were very specific and mentioned the following benefits: Alignment of the design of different disciplines (Org. 12 and 36); discovery of design errors before the construction phase (Org. 12 and 26); beneficial for large projects (Org. 11); advantages of the use of BIM software (Org. 5 and 12), proven benefits worldwide (Org. 12); work faster (Org. 24) and accurate representation of the planned project (Org. 32). It can be noted that many of the distinct benefits specified by the interviewees are realised in the design and construction phase of a project (Sacks et al., 2018). That may infer that either their knowledge on BIM benefits is limited or that the organisations are interested in implementing BIM to improve their workflows and productivity only in these two phases, not throughout the project's life cycle.

Competitive advantage: The desire for innovation to remain competitive has been identified as a critical driver for BIM implementation (Eadie et al., 2013b; Smith, 2014). This driver was identified by 9 out of the 16 organisations of this study that do not implement BIM. On this subject, Interviewee 13 from Org. 8 argued: “... (BIM) places you in a different position in the market, in a competitive place. At a competitive level is not the same having a $2 \mathrm{D}$ rather than a model. You cannot compare". This statement reflects a misconception of the competitive advantage that BIM can offer, as the interviewee only considered the use of a 3D model. Furthermore, four interviewees from four organisations implementing BIM explained that the motivation to implement BIM was a competitive advantage to stand out from other organisations that were implementing traditional methods.

External pressure: External pressure is the stimulus generated from numerous entities in the competitive environment enclosing the organisation (Lee et al., 2015). Influence from other parties significantly impacts the company's decision to adopt BIM (Ahuja et al., 2016). For example, interviewee 18 from Org. 13 stated that the organisation is interested in BIM after an associate partner introduced it to them. Furthermore, Interviewee 36 from Org. 25 and Interviewee 46/I from Org. 32 explained that BIM had been demanded by international organisations they work with:

"Right now, we have a project in Punta Cana with a South African company, and they implement BIM like in Europe [...]. Since last year, there have been some projects where BIM has been a requirement. Therefore, the company has considered it a necessity now."

Issues affecting their current involvement with BIM

The research also explored the issues that the organisations have faced in the process of transition and BIM implementation. These were of intra-organisational and inter-organisational nature (see Figure 3). 


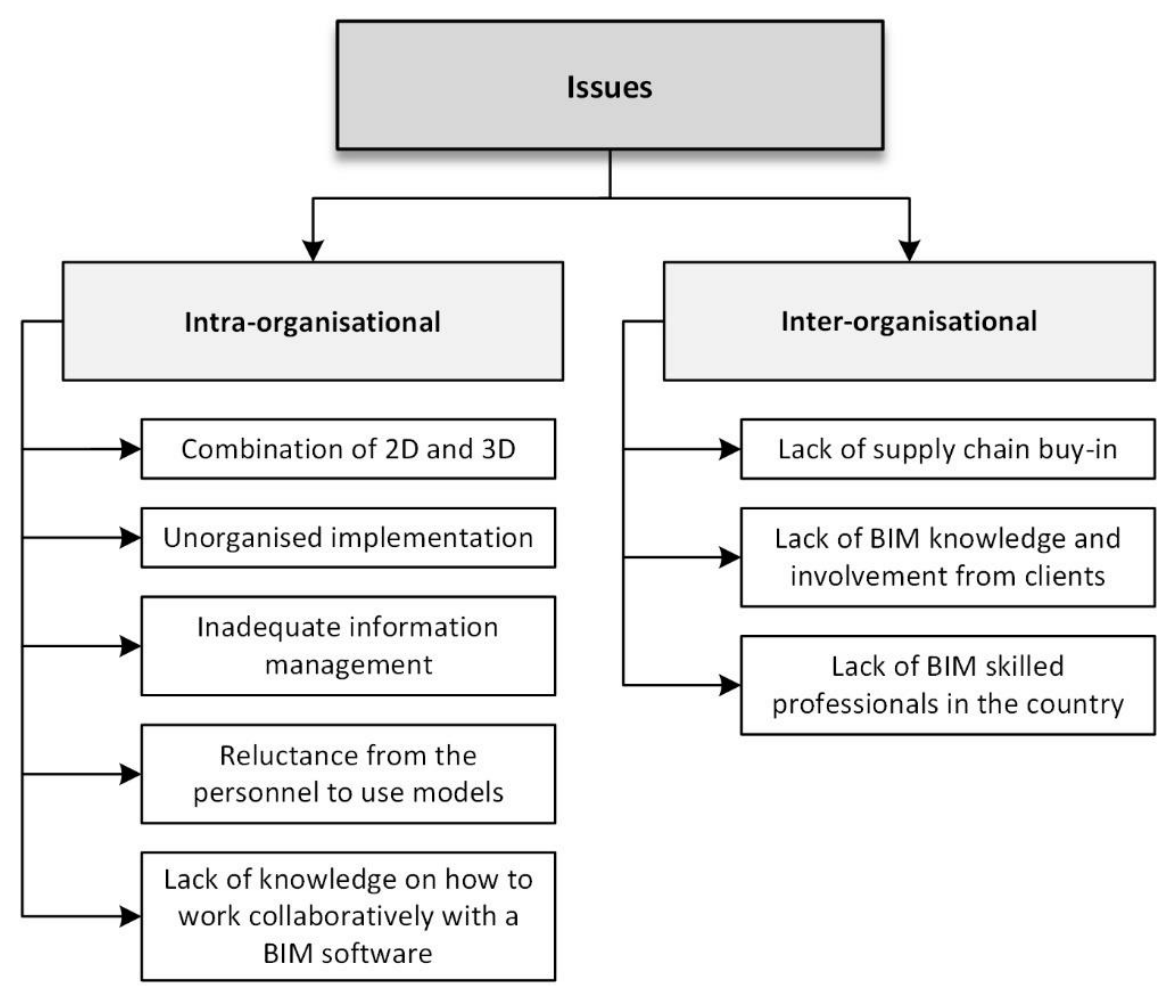

Figure 3: Issues affecting current involvement with BIM in organisations in transition to implementing BIM and organisations implementing BIM

The intra-organisational issues acknowledged by the interviewees include Combination of 2D and 3D software, Unorganised BIM implementation, Inadequate management of information, Reluctance to use models, and Lack of knowledge on how to work collaboratively.

Combination of $2 D$ and $3 D$ software: Interviewees from 7 organisations stated they still need to use 2D software in the organisations, more specifically AutoCAD 2D, in combination with BIM modelling software, which has affected the flow of information in the development of projects. Interviewees indicated the reasons why this has been needed: lack of BIM modelling skills of some staff, to facilitate the understanding of the least specialised workers, interoperability issues among modelling software, lack of BIM-object libraries for the Dominican context, and the use of 2D software to work on simple and old existing projects.

Unorganised BIM implementation. Interviewees from 4 organisations implementing BIM stated that they had not organised the implementation correctly. In this respect, Interviewee 25 from Org. 16 commented on this problem reflecting on their organisation and the Dominican construction industry: "We need to learn to program ourselves on time [...] this requires an organisation level we are not used to in this country. It might be, but that doesn't mean that is not possible. We can do it". Other comments such as 'Up to now, we are a little creative, a little bit unorganised' and 'We implement BIM empirically' also illustrates the tendency of implementing BIM without any planning.

Inadequate information management: Interviewees from Org. 5, 31 and 32 explained they were 
implementing improper methods for information management. In Org. 5 and Org. 31, the information of the projects is internally shared with USB flash drives. Furthermore, Interviewees from Org. 32 explained that they had asked external partners for hard copies because of the poor internet service in the office. Lastly, they stated they were reworking due to internal communication deficiencies: "We got to the point of defining codes for us to work because we did not understand each other; we were working twice”.

Other intra-organisational issues reported by one organisation include reluctance to use models from the personnel and lack of knowledge on how to work collaboratively with BIM software.

Interviewees from 3 organisations in transition and all the organisations implementing BIM identified issues of inter-organisational nature caused by Lack of supply buy-in, Lack of BIM knowledge and involvement of the client, and Lack of BIM skilled professionals in the country.

Lack of supply chain buy-in: Interviewees from 12 organisations stated that BIM implementation had been affected by the lack of knowledge and lack of BIM implementation in the construction supply chain. Interviewees from 3 organisations in transition to implementing BIM and 7 organisations implementing BIM commented about the non-use of BIM software as a relevant difficulty they have experienced with their external partners. Other problems pointed out include workload increment due to the rework and need of inserting information into the models (Xu et al., 2014); lack of integration of the different design disciplines in the models; delays in the completion of tasks; and lack of information in models:

"Simply if we give a Revit file and is given back to us in AutoCAD and we need to implement it here, that's a deficiency, that is backwardness in the delivery time, in the elaboration process. It takes valuable time from the employees" - Interviewee 37, Org. 26.

Other difficulties these organisations have faced due to the lack of supply buy-in are resistance to adopt BIM, identified by three organisations (Org. 12, 16, 18); and resistance to sharing information, recognised by two organisations (Org. 12, 32):

"Sometimes there are conflicts with the Designers and Contractors because they don't want to give you information. They think that you need to assume certain things. You know how people work here, that things are the way they are just because, and you need as much information as you can when you are modelling a BIM project." - Interviewee 20, Org. 12

Lack of BIM knowledge and involvement from clients: Interviewees from 3 organisations stated that clients had represented a barrier to proper BIM implementation because of their lack of BIM knowledge and involvement in the implementation. Interviewee 35 from Org. 24 pointed out that: "clients don't give you time, time for the company to prepare, time for training", inferring that clients do not understand the implementation process; therefore, they do not allow the organisation to invest the required time for the implementation. In contrast, Interviewee 32 from Org. 21 defends the position of clients when arguing: "Engineers are on-site, projects have a deadline, clients have even more pressure for the delivery. Telling them: "Hey, let's do it slowly because we want to implement something", that's not going to happen for now". The interviewee further 
commented: "We cannot say to a client: "We will do your project very slow because we want to implement BIM". The client will not understand this".

Lack of BIM skilled professionals in the country: Lastly, Interviewee 26 from Org. 12 commented that the organisation has slightly struggled to recruit BIM skilled people because of the shortage of BIM professionals in the country.

\section{Scope of the BIM implementation}

The organisations in this study classified as organisations implementing BIM do not do it across all their businesses. Instead, they do it in specific disciplines and processes, a limited approach still considered as valid. As per Gu and London (2010), the scope of BIM implementation is flexible and can be adopted in specific parts of the project lifecycle. The implementation of BIM can range from a complex and fully integrated multi-disciplinary BIM, where there is online collaboration, and every stage of the project can be updated in real-time, to a single disciplinary BIM implementation, where there are independent models for specific phases, sub-phases or tasks within a phase. Similarly, Coates et al. (2010) opined that an organisation could decide whether to implement BIM in a single or multi-disciplinary manner, noting that the main benefits can only be obtained through a multi-disciplinary approach.

Organisations 18, 21, 24 and 26 implement BIM intra-organisationally and at a disciplinary level only in Architectural design, despite these organisations also work in construction. Org. 11 is also an organisation where BIM implementation is usually limited to Architecture in terms of design. Interviewees 20, 21 and 23 stated that the implementation of BIM in Org. 12 is multi-disciplinary. $\mathrm{BIM}$ is used for clash detection, construction programming and project control. Org. 17 implements BIM only for the design disciplines they are involved with (i.e., electrical and plumbing), which are all subcontracted, and for construction programming. Org. 16 implements BIM for Architecture, Structure and Plumbing design. They also do clash detection in-house and supervise projects on-site. Lastly, Organisation 32 works on projects' control. They use BIM for project management, clash detection and quantity take-off.

Interviewees also indicated why BIM implementation is limited and has not surpassed other business processes in the organisations, which were classified into intra-organisational and interorganisational (see Figure 4). 


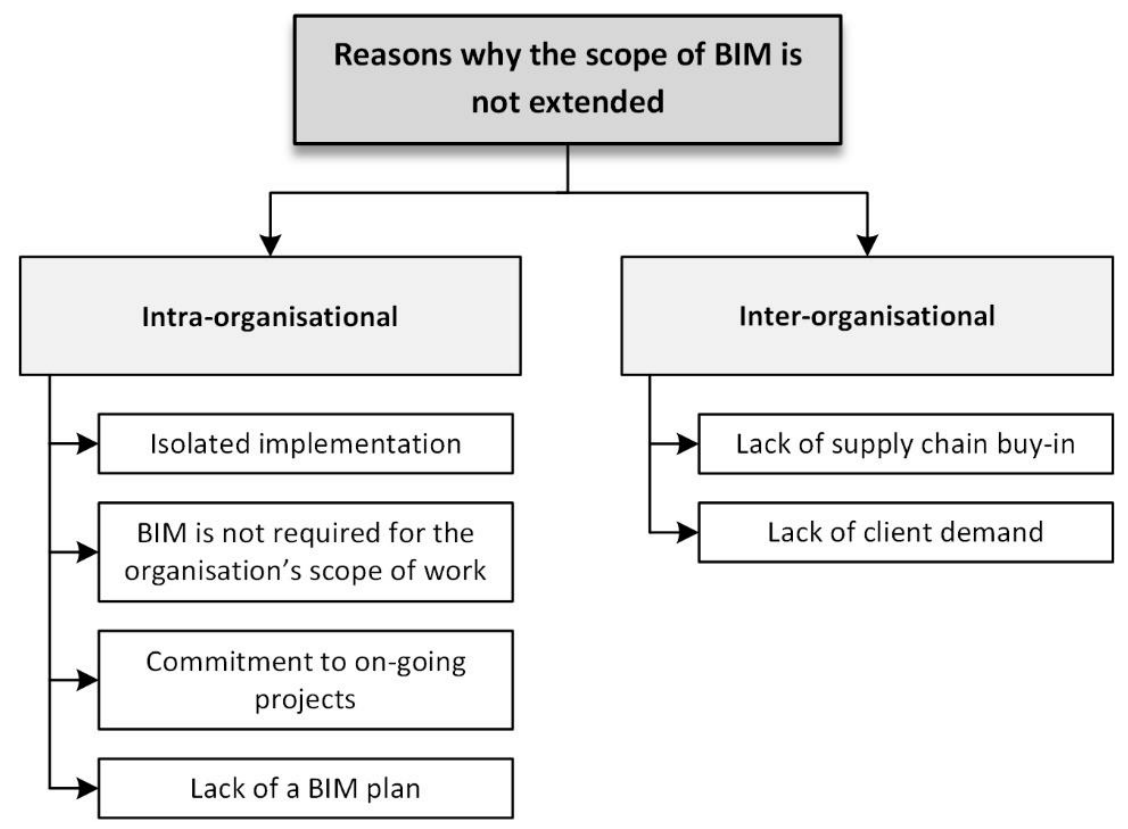

Figure 4: Reasons why the scope of BIM is not extended in organisations currently implementing BIM

The intra-organisational reasons identified by the interviewees are discussed below.

Isolated implementation: The implementation has not been fully realised in three organisations because it has been carried out in an isolated manner. In other words, the implementation has not included all the personnel from all disciplines. In this regard, Interviewee 16 from Org. 11 stated that the Architectural staff has been more prepared for the implementation; therefore, there are some deficiencies in the Engineering disciplines that do not allow them to expand their scope.

BIM is not required for the organisation's scope of work: Interviewee 27 from Org. 17 and Interviewee 37 from Org. 26 stated that BIM is not fully implemented because they considered a complete implementation unnecessary. Interviewee 27 argued: "I do not make the [software] investment because of the service I offer, and because clients do not demand a complete implementation either. If not, I'd do it", indicating that the decision does not only depends on the organisation's scope of work but also the client's demand. Interviewee 37 argued that: "We are a Design, Construction and Real Estate company. Currently, I consider that BIM works perfectly until the scope we have set [...]". The interviewee further said: "I consider that pure BIM works only for large companies, very efficient but with another scope. Maybe international companies take advantage of BIM", reflecting that a complete BIM implementation can be realised only in large enterprises and the international market, not in the DR. One part of this argument is consistent with Ghaffarianhoseini et al. (2017) statement that any relevant BIM benefits are more likely to be spread in large organisations since they are the leading BIM adopters.

Commitment to ongoing projects: According to Singh and Holmström (2015), stakeholders tend to concentrate on ongoing projects that are economically successful and entail risk mitigation. This 
aspect hinders BIM adoption in the industry because the long-term benefits of BIM adoption are usually ignored to give preference to the short-term goals of these projects. For example, interviewee 32 from Org. 21 argued: "BIM is something new, and you cannot say: "Stop the work, let's learn something new to implement it". We cannot do that because you need to work and finish your projects on time, and this implementation takes a lot of time. We've been seeing, for a long time, and experimenting at a low pace, steadily but slowly [...] and we are not even closer.". This comment illustrates how an organisation's duties and the rigorousness of BIM implementation can slow down the progress of the implementation.

Lack of a BIM plan: Interviewee 21 from Org. 12 opined that BIM is not fully implemented because the organisation has not prepared a proper plan for these purposes: "If it is done and the resources are defined, it will be achievable. But a working plan has not been defined for the implementation of BIM in the company".

Intra-organisational reasons identified by the interviewees include Lack of supply chain buy-in and Lack of client demand.

Lack of supply chain buy-in: Lack of supply chain buy-in was considered a significant deterrent to expanding BIM implementation by 5 organisations. Interviewees stated they could implement $\mathrm{BIM}$ as much as possible in the design disciplines that are part of the organisations. Still, the continuation of BIM is not in their hands when external parties are involved: "but the problem is that it is not implemented $100 \%$ because the Design of other disciplines besides the Architectural is not included"- Interviewee 16, Org. 11.

Furthermore, Interviewee 23 discussed the difficulty of implementing IPD (Integrated Project Delivery), the ideal project delivery for BIM implementation, when working with members of the supply chain because of the mistrust among professionals in the country:

"We haven't been able to implement IPD 100\% because it is difficult in this country [...] because in this country we still have the conception that people will trickyou”.

Lack of client demand has been identified as a common reason why many firms do not invest and make the transition to BIM (Eadie et al., 2013a; Smith, 2014). Particularly, Interviewee 35 from Org. 24 identified it as a hindrance to have a broader implementation of BIM: "We do not implement it (BIM) 100\%, not because of BIM, but because of the client's requirements [...]. Yes, we mostly work with Architectural and Structural design. If the client demanded BIM, we would include more disciplines and add more information. We would have time to do it".

\section{Discussion}

The number of organisations implementing BIM in this study was limited. Only 9 out of 36 organisations were implementing BIM $(25 \%)$, in contrast with 5 organisations embarked on a transition process $(14 \%)$, and 22 organisations not implementing BIM at all. The reasons why Dominican construction organisations are not implementing BIM were categorised as intraorganisational and inter-organisational. Intra-organisational reasons included lack of BIM knowledge, resistance to change, BIM is perceived as complex and "BIM is not suitable for our projects". Lack of BIM knowledge points out the need to spread BIM knowledge across the 
Dominican construction sector and provide BIM education and training to prepare current and future professionals. Currently, BIM knowledge is disseminated through educational activities hosted by universities, professional bodies, and professional groups. There is also BIM training available, mainly focusing on teaching software, and BIM education is starting to emerge in Academia (Silverio et al., 2017; Silverio, 2020). Although these are positive actions, findings suggest that more efforts are needed for BIM knowledge to be more disseminated across industry practitioners. Thus far, current efforts come from Academia and the industry. More collaboration between these two players would allow information, skills and knowledge transfer between research and practice (Olawumi et al., 2019). Government support is also crucial in enabling massive BIM awareness in the industry. Governments in developing countries should promote BIM adoption by mandating its implementation (Babatunde et al., 2020). Nonetheless, BIM implementation in the DR has initiated with a bottom-up approach (Succar and Kasem, 2015) which has not influenced the Dominican government yet into making this decision.

Furthermore, it can be argued that the resistance to change reported by some of the organisations is linked to lack of BIM knowledge. These organisations see their current approaches as the only way of working regardless of the inefficiencies they may experience. Having a clear understanding of the benefits of BIM would help them realise that changing their way of work is important (Ayinla and Amadu, 2018). The perception of "BIM is not suitable for our projects" suggests the need for disseminating examples of good practices and successful BIM projects. As Al-Ashmori et al. (2020) indicated, successful case studies to demonstrate the efficiency of BIM and feasibility of attaining BIM benefits can encourage and increase BIM adoption. The massive diffusion of local examples or from similar construction industries (e.g., Latin American countries, developing countries and BIM infant countries) would be advantageous. This way, Dominican industry practitioners can have a broader understanding of the benefits of BIM that could be associated with the type of work they usually do. Lastly, the inter-organisational reason "lack of supply chain buyin" can be minimised progressively as more professionals become "BIM literate" through BIM education and training (Eadie et al., 2014), and the BIM implementation is more spread in the industry.

BIM benefits, competitive advantage and external pressure were recognised as the drivers to BIM implementation in the Dominican construction industry. BIM benefits were a driver identified by the three types of organisations. The comments about BIM benefits were quite general, especially from organisations that do not implement BIM, which denotes awareness but limited knowledge on BIM benefits. As per Al-Ashmori et al. (2020), understanding and recognising the benefits of BIM helps construction professionals to decide on implementing BIM in their projects. But for that, it is important to identify these benefits so professionals can be persuaded about their effectiveness. Therefore, the benefits of BIM implementation must be identified and understood in the Dominican construction industry, especially benefits within their local context, so professionals can see its value and consider its implementation. Competitive advantage was identified by organisations not implementing and organisations implementing BIM. Lastly, pressure from external partners was identified by organisations implementing BIM.

Also, the few efforts identified from organisations involved with the implementation have not been realised satisfactorily due to the relevance and wide range of intra-organisational and interorganisational barriers affecting these organisations. BIM is mainly implemented at a disciplinary 
level, with Architecture being the most predominant discipline. These results are consistent with other studies. Designers have been the earliest BIM adopters (McGraw-Hill Construction, 2014b), and architects are very active in implementing BIM ( $\mathrm{Gu}$ and London, 2010). Architectural firms are usually in the lead of implementing BIM (Ahuja et al., 2018) and are acknowledged as significant contributors to BIM projects (Adam et al., 2021). Certainly, architects are the first professionals affected by BIM implementation because they participate in the early stages of a project. They also play an important role in introducing BIM implementation because of their notable input in creating information models for project integration (Juan et al., 2017). However, the implementation needs to be extended to all the disciplines involved in a project to maximise benefits (Coates et al., 2010). Hence, awareness of the benefits of multi-disciplinary approaches and collaborative practices, the provision of BIM education and training in all construction disciplines and guidance on how this can be achieved is vital for multi-disciplinary BIM implementation to grow in the country.

Findings corroborate that the DR is a BIM infant country. A BIM infant country is a country whose construction industry does not develop any BIM project; however, it is interested in implementing BIM in the future (Jayasena and Weddikkara, 2013; Rogers et al., 2015). Saka et al. (2020) further stated that most construction industries from developing countries are BIM infants, still experiencing difficulties adopting and implementing BIM. Both statements define the situation of the Dominican construction industry concerning BIM. The current scope of BIM implementation in the Dominican Republic is limited to specific disciplines and tasks; however, there is a general interest in BIM. Organisations already involved with the implementation and those in transition are still making efforts despite the barriers, mainly because they know the benefits they can get from the implementation. Those not implementing are also affected by relevant barriers, but many are still opened to implement it in the future.

As indicated by Succar and Kassem (2015), governments and authorities implementing BIM worldwide can pressure similar entities in other markets to implement BIM through what is known as top-down diffusion. The global examples of BIM implementation, especially the recent surge of BIM in Latin American countries, can positively influence the DR and enable a top-down diffusion. Therefore, studying BIM implementation in these countries, learning from their experience, and evaluating the appropriateness of their strategies in the DR context can be advantageous. Also, the participation of the DR in the BIM Forum Latam and the diffusion of a Dominican BIM project in the last Latin American BIM survey can open the doors for collaboration between the DR and Latin American countries, which can subsequently strengthen BIM implementation efforts in the country.

\section{Conclusion}

This research looked into the implementation of BIM in the Dominican Republic through Dominican construction organisations. For that, participant organisations were classified according to their BIM involvement in organisations that do not implement BIM, organisations in transition to implementing BIM and organisations implementing BIM. Studying the organisations that do not implement BIM shed light on why BIM is not implemented in the organisations and illustrated the openness and drivers for future BIM implementation. The study of the organisations in transition to implementing BIM and implementing BIM showed the drivers that have motivated the implementation of BIM and issues affecting their current involvement with BIM. Lastly, with 
the organisations implementing BIM, it was possible to analyse the scope of BIM implementation and the factors that have defined their current scope.

The Dominican Republic has been categorised as a BIM infant country, with a high interest in implementing BIM but experiencing difficulties in achieving this aim. Currently, there are low levels of BIM implementation and approaches to BIM implementation are highly affected by internal and external factors within the organisations. The implementation of BIM is mainly realised intra-organisationally and at a disciplinary level, where Architecture design prevails.

Lack of BIM knowledge was identified as a reason why organisations were not implementing $\mathrm{BIM}$, which is also connected with other reasons such as resistance to change, "BIM is not suitable for our projects and lack of supply chain buy-in. Moreover, lack of supply chain buy-in was identified as an important factor that hinders BIM implementation in Dominican construction organisations. It was recognised as one of the reasons why organisations do not implement BIM. It was also reported as the cause of several weaknesses in the implementation of BIM in organisations implementing BIM and the transition process of the organisation in transition to implementing BIM. Lastly, it was perceived to be an obstacle for the organisations implementing BIM to broaden the scope of their current implementation.

Based on the current status of BIM, several recommendations for implementing BIM in the country were posed. First, greater collaboration between Academia and the industry is required to increase and enhance current actions of disseminating BIM knowledge and the provision of BIM training and education. Second, the low levels of BIM implementation and limited knowledge on BIM benefits suggest that it is vital to diffuse examples of BIM projects in the Dominican construction industry, preferably local examples or similar industries, to encourage BIM implementation among practitioners. Lastly, BIM is primarily implemented in the Architecture field; hence, it is necessary to extend the actions mentioned above across all the disciplines within the construction industry to increase multi-disciplinary and collaborative practices in current and future implementation approaches.

Government support is fundamental for implementing BIM; however, the Dominican government is not pushing the implementation. The current status of BIM in the DR indicates a bottom-up approach to BIM implementation, with efforts from the industry and Academia. Actions from both do not have a national character but could eventually influence the government into taking the steps for driving the implementation of BIM, for which collaboration among the three is essential. In addition, collaboration with international entities is emerging with the recent involvement in the BIM forum Latam and the international exposure of one BIM project from the DR.

This research is of great importance because it presents empirical data about BIM implementation in the DR that is not available in the current literature. Having a national strategy would provide the required leadership and guidance that Dominican construction organisations and professionals need to implement BIM successfully in practice. The findings can thus be used as a basis for evaluating and developing strategies and guidelines for implementing BIM in the country. These can be used potentially by current drivers, namely industry and Academia, and subsequently by the government once it gets involved. In addition, there is a breadth to inquire more about BIM implementation in the DR, especially since the implementation is currently evolving. Hence, these findings can also be used as a starting point for further research on the topic. This research may 
benefit individual practitioners, construction organisations and governmental entities from the DR or similar countries (i.e., developing countries, BIM infant countries) and researchers interested in this study area.

This study presents some limitations, which are explained below:

- Currently, there are initiatives from the government to drive digitalisation in the country, but none of them is related to BIM implementation. Therefore, construction organisations were the starting point to investigate the implementation of BIM in the country. In addition, other studies involving governmental entities are suggested to explore how the government might drive the implementation.

- This research studied the status of BIM in the country through evaluating construction organisations. Further studies could consider studying BIM implementation at a project level when BIM implementation in the country is more spread and advanced.

\section{References}

ABDI (Agencia Brasileira de Desenvolvimiento Industrial) (2021), "BIM BR Construcao Inteligente", available at: https://estrategiabimbr.abdi.com.br/ (accessed 1 May 2021).

Adam, V., Manu P., Mahamadu, A.M., Dziekonski, K, Kissi E., Emuze F. and Lee, S. (2021), "Building information modelling (BIM) readiness of construction professionals: the context of the Seychelles construction industry", Journal of Engineering Design and Technology, Vol. ahead-of-print No. ahead-of-print.

Ahuja, R., Jain, M., Sawhney, A. and Arif, M. (2016), “Adoption of BIM by architectural firms in India: technology-organisation-environment perspective", Architectural Engineering and Design Management, Vol. 12 No.4, pp. 311-330.

Ahuja, R., Sawhney, A. and Arif, M. (2017), "Prioritising BIM Capabilities of an Organisation: An Interpretive Structural Modeling Analysis”, Procedia Engineering, Vol. 196, pp. 2-10.

Ahuja, R., Sawhney, A., Jain, M., Arif, M. and Rakshit, S. (2018), "Factors influencing BIM adoption in emerging markets-the case of India", International Journal of Construction Management, Vol. 10 No. 1, pp. 65-76.

Al-Ashmori, Y.Y., Othman, I., Rahmawati, Y., Amran, Y.M., Sabah, S.A., Rafindadi, A.D.U. and Mikić, M., (2020), "BIM benefits and its influence on the BIM implementation in Malaysia” Ain Shams Engineering Journal, Vol. 11 No. 4, pp.1013-1019.

Arias, M. (2018) “MOPC lanzará página web para agilizar licencias de construcción”, available at: $\quad$ http://z101digital.com/mopc-lanzara-pagina-web-para-agilizar-licencias-deconstruccion/ (accessed 20 October 2018).

Ayinla, K.O. and Adamu, Z. (2018), "Bridging the digital divide gap in BIM technology adoption", Engineering, Construction and Architectural Management, Vol. 25 No. 10, pp. 1398-1416.

Azhar, S. (2011), "Building information modeling (BIM): Trends, benefits, risks, and challenges for the A.E.C. industry, Leadership and Management in Engineering, Vol. 11 No. 3, pp. 241252. 
Babatunde, S.O., Ekundayo, D., Adekunle, A.O. and Bello, W., (2020), "Comparative analysis of drivers to BIM adoption among A.E.C. firms in developing countries", Journal of Engineering, Design and Technology, Vol 18 No. 6, pp. 1425-1447.

Banco Central de la Republica Dominicana (2021), "Banco Central informa que la economía dominicana registra un crecimiento de $1.1 \%$ en febrero de 2021 ", available at: https://www.bancentral.gov.do/a/d/5050-banco-central-informa-que-la-economiadominicana-registra-un-crecimiento-de-11-en-febrero-de-2021 (accessed 14 April 2021).

Batarseh, S. and Kamardeen, I., (2017), "The impact of individual beliefs and expectations on BIM adoption in the A.E.C. Industry" EPiC Series in Education Science, Vol. 1, pp.466-475.

Bengtsson, M. (2016), "How to plan and perform a qualitative study using content analysis", NursingPlus Open, Vol. 2, pp. 8-14.

BIM Wiki (2018), "Global BIM market", available at: https://www.designingbuildings.co.uk/wiki/Global_BIM_market (accessed 20 July 2019).

BIM Forum Argentina (2018) "Presentacion Estrategia BIM", available at: http://www.bimforum.org.ar/novedades/ampliar/presentacin-estrategia-bim-argentina(accessed 17 August 2019).

BIM Forum Chile (2017), "BIM Forum Chile asume coordinación de BIM Forum Latam", available at: http://www.bimforum.cl/2017/07/26/bim-forum-chile-asume-coordinacion-debim-forum-latam/\# (accessed 3 January 2018).

BIM Forum Latam (2020) "BIM Forum Dominican Republic", available at: https://www.linkedin.com/company/bimforumlatam/ (accessed 10 February 2021).

Bryde, D., Broquetas, M. and Volm, J.M. (2013), "The project benefits of building information modelling (BIM)", International Journal of Project Management, Vol. 31 No. 7, pp. 971980.

Bryman, A. (2016), Social research methods, Oxford university press, Oxford.

Bui, N., Merschbrock, C. and Munkvold, B.E. (2016), "A review of Building Information Modelling for construction in developing countries", Procedia Engineering, Vol. 164, pp. 487-494.

BuildingSMART Spain (2019) “Argentina y Peru anuncian sus estrategias de implementacion BIM”, available at: https://www.buildingsmart.es/2019/09/10/argentina-y-per\%C3\%BAanuncian-sus-estrategias-de-implementaci\%C3\%B3n-bim/ (accessed 15 June 2021).

CADOCON (2020) "BIM Forum promueve nueva tecnologia en construccion" available at:https://cadocon.org/portada/bim-forum-promueve-nueva-tecnologia-en-construccion/ (accessed 14 May 2020).

CAMACOL (2020), "Estrategia BIM Colombia proyecta para 2026 que la totalidad de los proyectos de cosntruccion publicos incorpore BIM", available at: https://camacol.co/comunicados/estrategia-bim-colombia-proyecta-para-2026-que-latotalidad-de-los-proyectos-de (accessed 12 June 2021). 
Cao, D., Wang, G., Li, H., Skitmore, M., Huang, T. and Zhang, W. (2015), "Practices and effectiveness of building information modelling in construction projects in China", Automation in Construction, Vol. 49, pp. 113-122.

Charmaz, K. (2006), Constructing Grounded Theory: A Practical Guide through Qualitative Analysis, SAGE Publications, London.

Cho, J.Y. and Lee, E. (2014), "Reducing confusion about grounded theory and qualitative content analysis: Similarities and differences", Qualitative Report, Vol. 19 No. 32, pp. 1-20

CIA (2020) "The World Factbook", available at: https://www.cia.gov/the-worldfactbook/countries/dominican-republic/ (accessed 7 May 2021).

Coates, P., Arayici, Y., Koskela, K., Kagioglou, M., Usher, C. and O'Reilly, K. (2010), “The key performance indicators of the BIM implementation process", available at: http://usir.salford.ac.uk/id/eprint/9551/5/ID_15_camera_ready.pdf (accessed 15 February 2015).

Construye 2025 (2016), “¿Que es Construye 2025?”, available at: http://www.construye2025.cl/que-es-construye-2025/ (accessed 15 February 2018).

Creswell, J.W. (2014), Research design: qualitative, quantitative, and mixed methods approaches, Fourth ed. SAGE Publications.

Creswell, J.W. and Poth, C.N. (2017), Qualitative inquiry and research design: Choosing among five approaches. Sage publications, C.A.

Department for International Trade (2020), "Exporting to Dominican Republic", available at: https://www.great.gov.uk/markets/dominican-republic/ (accessed 20 April 2021).

Eadie, R., Browne, M., Odeyinka, H., McKeown, C. and McNiff, S. (2013a), "BIM implementation throughout the UK construction project lifecycle: An analysis", Automation in Construction, Vol. 36, pp. 145-151.

Eadie, R., Odeyinka, H., Browne, M., McKeown, C. and Yohanis, M. (2013b), "An analysis of the drivers for adopting building information modelling", Journal of Information Technology in Construction (ITcon), Vol. 18, No. 17, pp. 338-352.

Eadie, R., Odeyinka, H., Browne, M., Mahon, C. and Yohanis, M. (2014), "Building Information Modelling Adoption: An Analysis of the Barriers of Implementation", Journal of Engineering and Architecture, Vol. 2, No.1, pp.77-101.

Elo, S. and Kyngäs, H. (2008), “The qualitative content analysis process", Journal of advanced nursing, Vol. 62 No. 1, pp. 107-115.

Ghaffarianhoseini, A., Tookey, J., Ghaffarianhoseini, A., Naismith, N., Azhar, S., Efimova, O. and Raahemifar, K. (2017), "Building Information Modelling (BIM) uptake: Clear benefits, understanding its implementation, risks and challenges, Renewable and Sustainable Energy Reviews, Vol. 75, pp. 1046-1053.

$\mathrm{Gu}$, N. and London, K. (2010), "Understanding and facilitating BIM adoption in the A.E.C. industry", Automation in Construction, Vol. 19 No. 8, pp. 988-999. 
Hsieh, H. and Shannon, S.E. (2005), "Three approaches to qualitative content analysis", Qualitative health research, Vol. 15 No. 9, pp. 1277-1288.

Hua, Y. (2014), “The Role of Innovation Culture in BIM Diffusion in Construction: Case Studies of Chinese Construction Firms", paper presented at the 18th Pacific Association of Quantity Surveyors Congress 2014, 7-10 June, Hong Kong, available at: https://www.researchgate.net/publication/267869053 THE_ROLE_OF_INNOVATION_C ULTURE IN BIM DIFFUSION IN CONSTRUCTION CASE STUDIES OF CHINE SE_CONSTRUCTION_FIRMS

INCONET (2017), "Primera Encuesta BIM Latinoamericana. Rescultados 2017", available at: https://www.bimforum.cl/2017/08/14/resultados-primera-encuesta-bim-latinoamericana/ (accessed 16 July 2018).

Ismail, N.A.A., Chiozzi, M. and Drogemuller, R., (2017), "An overview of BIM uptake in Asian developing countries”, in A.I.P. Conference Proceedings, A.I.P. Publishing L.L.C., pp. 080008-1-080008-7.

Jayasena, H. S. and Weddikkara, C. (2013), "Assessing the BIM maturity in a BIM infant industry", in Proceedings of the Second World Construction Symposium 2013: SocioEconomic Sustainability in Construction. Colombo, Sri Lanka, pp.14-15.

Lacaze, L. (2020), "Encuesta BIM America Latina y El Caribe 2020", available at: https://publications.iadb.org/publications/spanish/document/Encuesta-BIM-AmericaLatina-y-el-Caribe-2020.pdf (accessed 17 December 2020).

Lee, S., Yu, J. and Jeong, D. (2015), "BIM Acceptance Model in Construction Organizations", Journal of Management in Engineering, Vol. 31 No. 3, pp. 4014048-1-4014048-13.

Li, J., Greenwood, D. and Kassem, M. (2019), "Blockchain in the built environment and construction industry: A systematic review, conceptual models and practical use cases", Automation in Construction, Vol. 102, pp. 288-307.

Liu, S., Xie, B., Tivendal, L. and Liu, C. (2015), "Critical barriers to BIM implementation in the A.E.C. industry", International Journal of Marketing Studies, Vol 7 No. 67, pp. 162-171.

Mahamadu, A.M., Navendren, D., Manu, P., Joseph, R. and Dziekoński, K. (2017), “Addressing challenges to building information modelling implementation in UK: Designers' perspectives", available at: https://uwe-repository.worktribe.com/output/883543/addressingchallenges-to-building-information-modelling-implementation-in-uk-designersperspectives (accessed 22 January 2018).

McGraw-Hill Construction (2014a), "The Business Value of BIM for Construction in Major Global Markets: How Contractors Around the World Are Driving Innovation With Building Information Modeling", available: https://www.construction.com/toolkit/reports/bim-business-value-construction-globalmarkets (accessed 16 July 2014).

McGraw-Hill Construction (2014b), "The business value of BIM owners", available at: https://www.i2sl.org/elibrary/documents/Business Value of BIM for Owners SMR (20 14).pdf (accessed 16 July 2014). 
Mckinsey Global Institute (2017), "Reinventing construction: A route to higher productivity", available at: https://www.mckinsey.com/ (accessed 16 July 2018).

MEF (2020), "Sobre el Plan BIM Peru", available at: https://www.mef.gob.pe/planbimperu/planbim.html (accessed 10 June 2021).

Mehran, D. (2016), "Exploring the Adoption of BIM in the U.A.E. Construction Industry for A.E.C. Firms", Procedia Engineering, Vol. 145, pp. 1110-1118.

Merschbrock, C. and Munkvold, B.E. (2015), "Effective digital collaboration in the construction industry - A case study of BIM deployment in a hospital construction project" Computers in Industry, Vol. 73, pp. 1-7.

Mideplan (2019), "Estrategia Nacional BIM Costa Rica", available at: https://documentos.mideplan.go.cr/share/s/MOQwz7ifQI6vwczIxnFldw (accessed 14 June 2021).

Mideplan (2020), "Metodología BIM modernizará la construcción de infraestructura pública", available at: https://www.mideplan.go.cr/metodologia-bim-modernizara-la-construccionde-infraestructura-publica (accessed 14 June 2021).

Ministerio de la presidencia (2016a), “Que es Republica digital?”, available at: https://republicadigital.gob.do/que-es-republica-digital/ (accessed 12 July 2017).

Ministerio de la presidencia (2016b), "Gobierno digital, abierto y transparente", available at: https://republicadigital.gob.do/eje/gobierno-digital-abierto-y-transparente/ (accessed 16 November 2017).

Ministerio de Obras Publicas (2020), "SIBIM", available at: https://ppo.obraspublicas.gob.ar/SIBIM/Library/Index (accessed 15 May 2021)

Olawumi, T.O. and Chan, D.W., (2019), "Development of a benchmarking model for BIM implementation in developing countries”, Benchmarking: An International Journal, Vol 26 No. 4, pp.1210-1232.

Portal Oficial de la Republica Dominicana (2016), “Sabes que es el Gobierno Electronico?”, available at: http://www.dominicana.gob.do/index.php/e-sociedad/2014-12-17-20-08-19 (accessed 12 July 2017).

Portal oficial del Estado Argentino (2019), "Plan de implementacion de metodologia BIM para obra publica", available at: https://www.argentina.gob.ar/noticias/plan-de-implementacionde-metodologia-bim-para-obra-publica (accessed 10 February 2021).

Presidencia de la Republica Dominicana (2021), "Presidente Abinader crea el Gabinete de Transformación Digital, available at: https://presidencia.gob.do/noticias/presidenteabinader-crea-el-gabinete-de-transformacion-digital (accessed 15 April 2021).

Rahim, N.S.A. and Zakaria, S.A.S. (2017), "The Framework of Building Information Modeling (BIM) Implementation Stages for Malaysian Construction Industry", IPTEK Journal of Proceedings Series, Vol. 3 No. 6, pp. 62-68.

Red BIM Gob Latam (2020a). "Avance de la implementación de BIM en Latinoamérica", available at: https://www.redbimgoblatam.com/inicio (accessed 15 February 2021). 
Red BIM Gob Latam (2020b), "Seminario Avance de la implementación de BIM en Latinoamérica", available at: https://www.youtube.com/watch?v=bFlECa5_ge0 (accessed 15 February 2021).

Rogers, E.M. (1995), Diffusion of innovations, 3. Ed., The Free Press, New York, N.Y.

Rogers, J., Chong, H., Preece, C., Lim, C.C. and Jayasena, H.S. (2015), BIM Development and Trends in Developing Countries: Case Studies, Bentham Science Publishers, Sharjah, U.A.E.

Sacks, R., Eastman, C., Lee, G. and Teicholz, P. (2018), BIM handbook a guide to building information modeling for owners, designers, engineers, contractors, and facility managers, 3 ed., John Wiley \& Sons. Hoboken, New Jersey.

Saunders, M., Lewis, P. and Thornhill, A. (2019), Research Methods for Business Students, Eighth ed., Pearson Education, London.

SECOVI-SP (2017), "Governo federal cria comitê estratégico de implementação do BIM", available at: http://www.secovi.com.br/noticias/governo-federal-cria-comite-estrategico-deimplementacao-do-bim/13026 (accessed 16 February 2018).

Senior, B. A. and Rodriguez, T. A. (2012), "Analysing Barriers to Construction Productivity Improvement in the Dominican Republic", paper presented at the 20th Annual ConferenceInternational Group for Lean Construction (IGLC-20), July 2012, San Diego, CA, U.S.A., available at: https://iglcstorage.blob.core.windows.net/papers/attachment-84de6b5a-b31947be-bc0d-a9e5ef7d590b.pdf

SHCP (2019), "Estrategia para la implementation del modelado de information de la Construccion (MIC) en Mexico", available at: https://www.gob.mx/shcp/documentos/plan-estrategico-

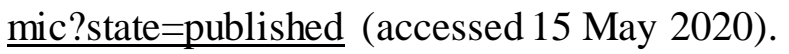

Silverio, A.K., (2020), "Implementation of building information modelling in the Dominican Republic construction industry: available at: https://wlv.openrepository.com/handle/2436/623695 (accessed 10 November 2020).

Singh, V. and Holmström, J. (2015), "Needs and technology adoption: observation from BIM experience", Engineering, Construction and Architectural Management, Vol. 22 No. 2, pp. 128-150.

Smith, P. (2014), "BIM implementation-global strategies", Procedia Engineering, Vol. 85, pp. 482-492.

Soler, J., Salcedo, N. and Núñez, Y. (2013), "Estudio prospectivo de la formación profesional del sector de la construcción civil", available at: http://www.oitcinterfor.org/node/5539 (accessed 10 May 2015).

Soto, C. (2016), “Seminario BIM Estrategia Publica al 2020”, available at: https://www.bimforum.cl/2016/11/29/seminario-bim-estrategia-publica-2020/ (accessed 20 May 2017).

Succar, B. (2009), "Building information modelling framework: A research and delivery foundation for industry stakeholders", Automation in Construction, Vol. 18 No. 3, pp. 357375 . 
Succar, B. and Kassem, M. (2015), "Macro-BIM adoption: Conceptual structures", Automation in Construction, Vol. 57, pp. 64-79.

Uruguay Presidencia (2019), "Tecnología que reduce costos y errores en la construcción próxima a ser utilizada en Uruguay", available at: https://www.presidencia.gub.uy/comunicacion/comunicacionnoticias/metodologia-bimvictor-rossi-alvaro-ons-construccion-ingenieria-civil-(accessed 12 June 2021).

Vaismoradi, M., Turunen, H. and Bondas, T. (2013), "Content analysis and thematic analysis: Implications for conducting a qualitative descriptive study" Nursing \& health sciences, Vol. 15 No. 3, pp. 398-405.

World Economic Forum (2018), "An action plan to accelerate building information modeling adoption", available at: http://www3.weforum.org/docs/WEF_Accelerating_BIM_Adoption_Action_Plan.pdf (accessed 19 August 2019).

$\mathrm{Xu}, \mathrm{H} .$, Feng, J. and Li, S. (2014), "Users-orientated evaluation of building information model in the Chinese construction industry", Automation in Construction, Vol. 39, pp. 32-46.

Zahrizan, Z., Nasly, M.A., Ahmad, T.H., Marshall-Ponting, A. and Zuhairi, A.H. (2013), "Exploring the barriers and driving factors in implementing building information modelling (BIM) in the Malaysian construction industry: A preliminary study", Journal Institution of Engineers Malaysia, Vol. 75 No. 1, pp. 1-10. 